\title{
PROPAGATION OF A STRONG DISCONTINUITY IN A BINARY MIXTURE OF GASES
}

\author{
A. V. Krasilnikov ${ }^{1,2}$, press-csu@yandex.ru, \\ V. F. Kuropatenko ${ }^{1}$ \\ ${ }^{1}$ Russian Federal Nuclear Center - Academician E. I. Zababakhin All-Russian Research \\ Institute of Technical Physics, Russian Federation \\ ${ }^{2}$ South Ural State University, Chelyabinsk, Russian Federation
}

Strong discontinuities - shock-waves - arise in a continuous media under dynamic external loads. Simulation of their propagation in mixtures must take into account, for each mixture component, the mass, momentum, and energy conservation laws relating states of matter before and behind the shock front. This effort calculates the process of shock-wave propagation in a plane layer, i.e. a homogeneous mixture of two gases having different density. For this purpose, conservation laws, as well as quantities responsible for components interaction were numerically implemented. The Lagrangian stage of the Lagrangian - Eulerian calculations used the shock-wave computation method based on the solution of the system of nonlinear algebraic equations. Sensitivity of flow parameters to the cluster and pairwise interactions is investigated. Cluster interaction was shown to be the major contributor to velocities relaxation behind the strong discontinuity front. Profiles of thermodynamic quantities and mass velocities were obtained for each component.

Keywords: multicomponent media; conservation laws; shock wave; Lagrangian Eulerian scheme; cluster interaction.

\section{Introduction}

In the one-dimensional case of a ideal continuous media consisting of $N$ components, conservation laws of mass, momentum, and energy, as well as the equation of volume concentration of the $i$-th component in the Lagrangian coordinates for the plane symmetry in [1] are written as

$$
\begin{gathered}
\frac{d_{i}\left(\alpha_{i} \rho_{i}\right)}{d t}+\left(\alpha_{i} \rho_{i}\right)^{2} \frac{\partial u_{i}}{\partial m_{i}}=0 \\
\frac{d_{i} u_{i}}{d t}+\frac{\partial}{\partial m_{i}}\left(\alpha_{i}\left[P_{i}+F_{i}\right]\right)-\frac{R_{i}}{\rho_{i}}=0 \\
\frac{d_{i} \varepsilon_{i}}{d t}+\frac{\partial}{\partial m_{i}}\left(\alpha_{i}\left[P_{i} u_{i}+F_{i} u_{i}+Q_{i}\right]\right)-\frac{\Phi_{i}+A_{i}}{\rho_{i}}=0, \\
\frac{d_{i} \alpha_{i}}{d t}+\alpha_{i} \rho_{i}\left(U-u_{i}\right) \frac{\partial \alpha_{i}}{\partial m_{i}}+\Omega_{i}+B_{i}=0,
\end{gathered}
$$

where $t$ is the time, $x$ is the mass coordinate, $\alpha_{i}$ is the volume concentration of the $i$-th component, $\rho_{i}$ is its density, $u_{i}$ is its mass velocity, $P_{i}$ is its pressure, $\varepsilon_{i}=E_{i}+0.5 u_{i}^{2}$ is the specific total energy, and $E_{i}$ is the specific internal energy. In addition, the equations include terms that depend on other components, i.e. $F_{i}$ is the force of cluster interaction between the $i$-th component and the mixture, $R_{i}$ is the aggregate momentum of other components pairwise action upon the $i$-th component, $Q_{i}$ is the flow energy directed to the 
$i$-th component, $\Phi_{i}$ is energy exchange during pairwise interaction for the $i$-th component, $A_{i}$ is the work of pairwise interaction for the $i$-th component, $\Omega_{i}$ is the function selected due to invariance of the equation of volume concentration to the Galilean transformation [2], $B_{i}$ is the function that considers velocity exchange during pairwise interaction in the equation for volume concentration, $U$ is the mass velocity of the mixture. $\frac{d_{i}}{d t}=\frac{\partial}{\partial t}+u_{i} \frac{\partial}{\partial x}$ the derivative along the trajectory of the $i$-th component (substantive).

The equation of state of the $i$-th component in the form

$$
P_{i}=f_{i}\left(\rho_{i}, E_{i}\right)
$$

is added to the system of equations (1)-(4), as well as the equation along the trajectory $\frac{d_{i} x}{d t}=u_{i}$.

The state of matter in the $i$-th component before and behind the shock front is described by the following system of nonlinear algebraic equations

$$
\begin{aligned}
\alpha_{i+} & =\alpha_{i-}, \\
\frac{1}{\rho_{i+}} W_{i}+u_{i+} & =\frac{1}{\rho_{i-}} W_{i}+u_{i-}, \\
u_{i+} W_{i}-P_{i+}-F_{i+} & =u_{i-} W_{i}-P_{i-}-F_{i-}, \\
\varepsilon_{i+} W_{i}-u_{i+}\left(P_{i+}+F_{i+}\right)-Q_{i+} & =\varepsilon_{i-} W_{i}-u_{i-}\left(P_{i-}+F_{i-}\right)-Q_{i-},
\end{aligned}
$$

where $W_{i}$ is the velocity of shock-wave propagation in the $i$-th component, index ' - ' is the state of matter before the shock front and index '+' - behind the shock front. Quantities before the discontinuity are assumed to be known. Jump in entropy across the shock-wave is associated with the energy dissipation mechanism. There are 4 different energy dissipation mechanisms [3]. We will use the method given in [4] and apply it to the multicomponent media. A sequence of equations is added in order to close the system of equations (5)-(8). One equation among them is the equation of state [5]:

$$
P_{i+}=f_{i}\left(\rho_{i+}, E_{i+}\right) .
$$

In this equation, the specific internal energy $E_{i+}$ is expressed in terms of $\varepsilon_{i+}$ and $u_{i+}$ as

$$
E_{i+}=\varepsilon_{i+}-0.5 u_{i+}^{2} .
$$

Another two equations are expressions for functions of cluster interaction, $F_{i+}$ and $Q_{i+}$ :

$$
\begin{gathered}
F_{i+}=-0.5 \rho_{i+}\left(u_{i+}-U_{+}\right)^{2}, \\
Q_{i+}=0.5 \rho_{i+}\left(U_{+}-u_{i+}\right)\left(P_{i+}+\rho_{i+} E_{i+}\right) .
\end{gathered}
$$

The mass velocity of the mixture, $U_{+}$is expressed in terms of components velocities:

$$
U_{+}=\sum_{i=1}^{N} \eta_{i} u_{i+},
$$

where $N$ is the number of components. Expressions for the mass concentration of $i$-th component and density of the mixture are defined as follows

$$
\eta_{i+}=\alpha_{i+} \rho_{i+} / \rho_{+}
$$




$$
\rho_{+}=\sum_{i=1}^{N} \alpha_{i} \rho_{i+} .
$$

The relation between the velocity of shock-wave propagation in the mixture $(W)$ and the appropriate velocity in the $i$-th component closes the system of equations:

$$
W_{i}=W\left(\frac{\rho_{i-} C_{i-}}{\rho_{-} C_{-}}\right)
$$

\section{Description of the Difference Scheme}

Practical experience of solving problems with multicomponent media [3] demonstrates that two-stage methods, wherein the first stage uses the difference scheme of computation in the Lagrangian coordinates, erase a number of difficulties and simplify the computational procedure. Consider the structure of any one of two-stage methods. At the first stage, the grid is interpreted to be the Lagrangian one. Any known method of computation in the Lagrangian coordinates is used to determine auxiliary quantities, $u_{i}^{*}$, $P_{i}^{*}, \alpha_{i}^{*}$, as well as main quantities at the time $t^{n+1}$. Here, the Eulerian coordinates of cell boundaries $x_{n}$ are varying and take on values $x_{j}^{n+1}$. At the second stage, a new grid is generated and the grid $x_{j}^{n+1}$ is re-interpolated onto this new grid. Re-interpolation is performed in accordance with the instantaneous $(t=$ const $)$ laws of mass, momentum, and energy conservation. The new grid can coincide with but also can differ from the initial Eulerian grid $x_{j}^{n}$ (moving Eulerian grid).

The divergence difference scheme developed by V. F. Kuropatenko [3] is used as the two-stage method. The mesh pattern is given in Fig. 1. All grid quantities are determined in the center of grid cells on the Lagrangian coordinate $m$. Boundary between cells at $m=m_{i}$ has the Eulerian coordinate $x_{i}^{n}$. At the time $t^{n+1}=t^{n}+\tau$ the Lagrangian coordinate $m_{i}$ remains the same but the Eulerian coordinate of the point is changing and takes on the value $x_{i}^{n+1}$.

\subsection{The Lagrangian Stage}

Evaluation of auxiliary quantities According to [4], it is necessary to find the auxiliary quantities $P_{i}^{*}, \alpha_{i}^{*}, u_{i}^{*}$. All cells are grouped into two types, i.e. cells wherein matter of $i$-th component is compressed $\left(\left(u_{i}\right)_{j+1}^{n}-\left(u_{i}\right)_{j}^{n}<0\right)$ and cells wherein grid rarefaction wave is present $\left(\left(u_{i}\right)_{j+1}^{n}-\left(u_{i}\right)_{j}^{n} \geq 0\right)$. For the first-type cells, the system of equations (5)(16) is resolved and such quantities of this system as the volume concentration, pressure, and velocity behind the shock front are taken as auxiliary quantities. For the second-type cells, equations (1)-(3) are approximated by difference equations.

Let us write out difference equations in order to find velocity, pressure, and volume concentration of the $i$-th component in the cell rarefaction wave

$$
\begin{aligned}
\left(u_{i}\right)_{k}^{*}=\left(u_{i}\right)_{k}^{n}-\frac{\tau}{2}[ & \frac{\left(\alpha_{i}\right)_{k+0.5}^{n}\left(\left(P_{i}\right)_{k+0.5}^{n}+\left(F_{i}\right)_{k+0.5}^{n}\right)}{\left(h_{i}\right)_{k}^{n}}- \\
& \left.-\frac{\left(\alpha_{i}\right)_{k-0.5}^{n}\left(\left(P_{i}\right)_{k-0.5}^{n}+\left(F_{i}\right)_{k-0.5}^{n}\right)}{\left(h_{i}\right)_{k}^{n}}+\frac{\left(R_{i}\right)_{k}^{n}}{\left(\rho_{i}\right)_{k}^{n}}\right],
\end{aligned}
$$




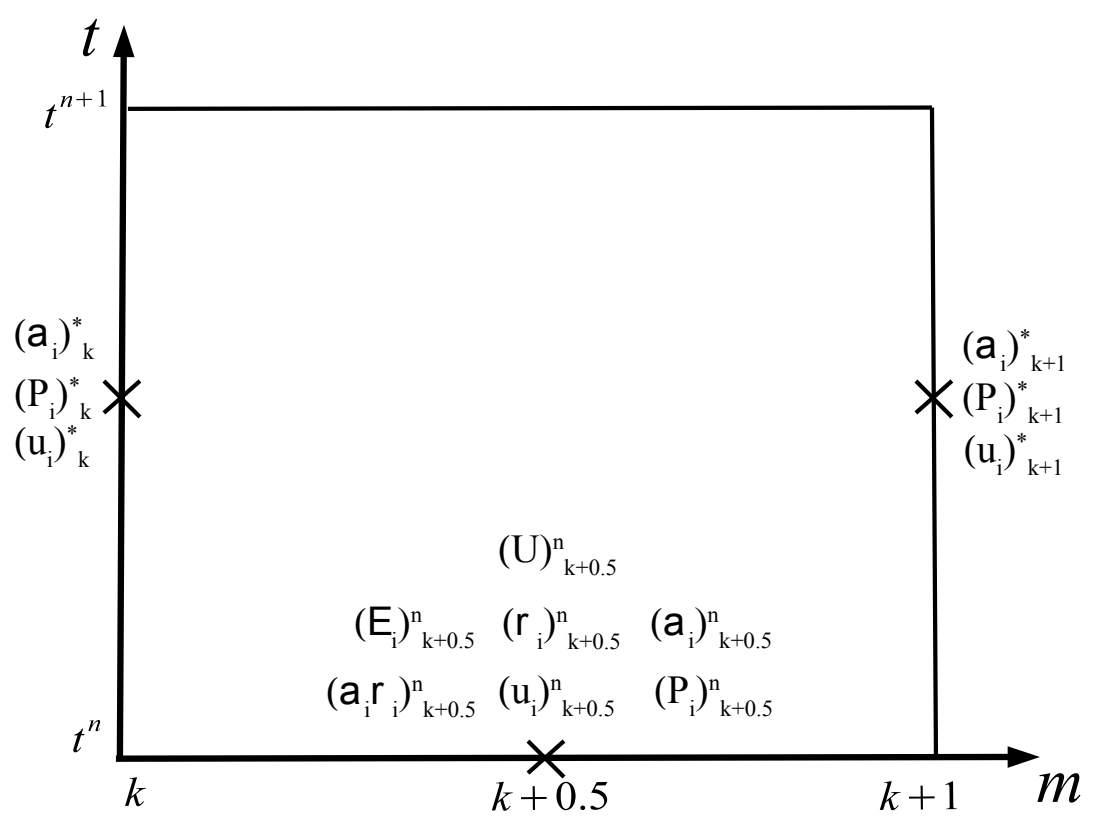

Fig. 1. Schematic distribution of quantities in a cell

$$
\begin{aligned}
& \left(P_{i}\right)_{k}^{*}=\left(P_{i}\right)_{k}^{n}-\frac{\tau}{2}\left[\left(\frac{\partial P_{i}}{\partial \rho_{i}}\right)_{E_{i}}\right]_{k}^{n}\left(\left(\rho_{i}^{2}\right)_{k}^{n} \frac{\left(\alpha_{i}\right)_{k}^{n}\left(\left(u_{i}\right)_{k+0.5}^{n}-\left(u_{i}\right)_{k-0.5}^{n}\right)}{\left(h_{i}\right)_{k}^{n}}-\left(\rho_{i}\right)_{k}^{n} \frac{\left(\Omega_{i}\right)_{k}^{n}+\left(B_{i}\right)_{k}^{n}}{\left(\alpha_{i}\right)_{k}^{n}}+\right. \\
& \left.+\frac{\left(U_{k}^{n}-\left(u_{i}\right)_{k}^{n}\right)\left(\left(\alpha_{i}\right)_{k+0.5}^{n}-\left(\alpha_{i}\right)_{k-0.5}^{n}\right)}{\left(h_{i}\right)_{k}^{n}}\right)-\frac{\tau}{2}\left[\left(\frac{\partial P_{i}}{\partial E_{i}}\right)_{\rho_{i}}\right]_{k}^{n}\left(\frac{\left(R_{i}\right)_{k}^{n}\left(u_{i}\right)_{k}^{n}-\left(\Phi_{i}\right)_{k}^{n}-\left(A_{i}\right)_{k}^{n}}{\left(\rho_{i}\right)_{k}^{n}}+\right. \\
& \left.+\frac{\left(\alpha_{i}\right)_{k}^{n}\left[\left(P_{i}\right)_{k}^{n}+\left(F_{i}\right)_{k}^{n}\right]\left(\left(u_{i}\right)_{k+0.5}^{n}-\left(u_{i}\right)_{k-0.5}^{n}\right)}{\left(h_{i}\right)_{k}^{n}}+\frac{\left(\alpha_{i}\right)_{k+0.5}^{n}\left(Q_{i}\right)_{k+0.5}^{n}-\left(\alpha_{i}\right)_{k-0.5}^{n}\left(Q_{i}\right)_{k-0.5}^{n}}{\left(h_{i}\right)_{k}^{n}}\right)
\end{aligned}
$$

where $\tau$ is the iteration step in time, $h_{i}$ is the iteration step in space and $\left(\rho_{i}^{2}\right)_{k}^{n}=\left[\left(\rho_{i}\right)_{k}^{n}\right]^{2}$. The equation for the volume concentration is written out as

$$
\left(\alpha_{i}\right)_{k}^{*}=\left(\alpha_{i}\right)_{k}^{n}-\frac{\tau}{2}\left[\frac{\left(\alpha_{i}\right)_{k}^{n}\left(\rho_{i}\right)_{k}^{n}\left(U_{k}^{n}-\left(u_{i}\right)_{k}^{n}\right)\left(\left(\alpha_{i}\right)_{k+0.5}^{n}-\left(\alpha_{i}\right)_{k-0.5}^{n}\right)}{\left(h_{i}\right)_{k}^{n}}+\left(\Omega_{i}\right)_{k}^{n}+\left(B_{i}\right)_{k}^{n}\right] .
$$

Here, the following notation is introduced

$$
\begin{aligned}
& {\left[\left(\frac{\partial P_{i}}{\partial \rho_{i}}\right)_{E_{i}}\right]_{k}^{n}=\frac{1}{2}\left(\left[\left(\frac{\partial P_{i}}{\partial \rho_{i}}\right)_{E_{i}}\right]_{k-0.5}^{n}+\left[\left(\frac{\partial P_{i}}{\partial \rho_{i}}\right)_{E_{i}}\right]_{k+0.5}^{n}\right)=} \\
& =\frac{P_{i}\left(\left(\rho_{i}\right)_{k-0.5}^{n}+\delta,\left(E_{i}\right)_{k-0.5}^{n}\right)-P_{i}\left(\left(\rho_{i}\right)_{k-0.5}^{n},\left(E_{i}\right)_{k-0.5}^{n}\right)}{2 \delta}+ \\
& +\frac{P_{i}\left(\left(\rho_{i}\right)_{k+0.5}^{n}+\delta,\left(E_{i}\right)_{k+0.5}^{n}\right)-P_{i}\left(\left(\rho_{i}\right)_{k+0.5}^{n},\left(E_{i}\right)_{k+0.5}^{n}\right)}{2 \delta},
\end{aligned}
$$




$$
\begin{aligned}
& {\left[\left(\frac{\partial P_{i}}{\partial E_{i}}\right)_{\rho_{i}}\right]_{k}^{n}=\frac{1}{2}\left(\left[\left(\frac{\partial P_{i}}{\partial E_{i}}\right)_{\rho_{i}}\right]_{k-0.5}^{n}+\left[\left(\frac{\partial P_{i}}{\partial E_{i}}\right)_{\rho_{i}}\right]_{k+0.5}^{n}\right)=} \\
& =\frac{P_{i}\left(\left(\rho_{i}\right)_{k-0.5}^{n},\left(E_{i}\right)_{k-0.5}^{n}+\delta\right)-P_{i}\left(\left(\rho_{i}\right)_{k-0.5}^{n},\left(E_{i}\right)_{k-0.5}^{n}\right)}{2 \delta}+ \\
& +\frac{P_{i}\left(\left(\rho_{i}\right)_{k+0.5}^{n},\left(E_{i}\right)_{k+0.5}^{n}+\delta\right)-P_{i}\left(\left(\rho_{i}\right)_{k+0.5}^{n},\left(E_{i}\right)_{k+0.5}^{n}\right)}{2 \delta},
\end{aligned}
$$

where $\delta<<1$.

Evaluation of main quantities. At the second stage, we find main quantities determined in middles of grid cells. As this takes place, cell boundaries change as

$$
x_{k}^{n+1}=x_{k}^{n}+\tau\left(u_{i}\right)_{k}^{*}
$$

and masses and partial densities in cells depend on the problem symmetry. Therefore, in the plane case $\left(h_{i}\right)_{k+0.5}^{n}=\left(\alpha_{i} \rho_{i}\right)_{k+0.5}^{n}\left(x_{k+1}^{n}-x_{k}^{n}\right)$,

$$
\left(\alpha_{i} \rho_{i}\right)_{k+0.5}^{n+1}=\frac{\left(h_{i}\right)_{k+0.5}^{n}}{x_{k+1}^{n+1}-x_{k}^{n+1}}
$$

The velocity at the next time step is

$$
\left(u_{i}\right)_{k+0.5}^{n+1}=\left(u_{i}\right)_{k+0.5}^{n}-\tau\left(\frac{\left(\alpha_{i}\right)_{k+1}^{*}\left[\left(P_{i}\right)_{k+1}^{*}+\left(F_{i}\right)_{k+1}^{n}\right]-\left(\alpha_{i}\right)_{k}^{*}\left[\left(P_{i}\right)_{k}^{*}+\left(F_{i}\right)_{k}^{n}\right]}{\left(h_{i}\right)_{k+0.5}^{n}}-\frac{\left(R_{i}\right)_{k+0.5}^{n}}{\left(\rho_{i}\right)_{k+0.5}^{n}}\right) .
$$

The specific internal energy is found from the formula

$$
\begin{aligned}
\left(E_{i}\right)_{k+0.5}^{n+1}= & \left(E_{i}\right)_{k+0.5}^{n}-\tau\left[\frac{\left(\left(\alpha_{i}\right)_{k+1}^{*}\left[\left(u_{i}\right)_{k+1}^{*}\left(\left(P_{i}\right)_{k+1}^{*}+\left(F_{i}\right)_{k+1}^{n}\right)+\left(Q_{i}\right)_{k+1}^{n}\right]\right.}{\left(h_{i}\right)_{k+0.5}^{n}}-\right. \\
& \left.-\frac{\left(\alpha_{i}\right)_{k}^{*}\left[\left(u_{i}\right)_{k}^{*}\left(\left(P_{i}\right)_{k}^{*}+\left(F_{i}\right)_{k}^{n}\right)+\left(Q_{i}\right)_{k}^{n}\right]}{\left(h_{i}\right)_{k+0.5}^{n}}-\frac{\left(A_{i}\right)_{k+0.5}^{n}+\left(\Phi_{i}\right)_{k+0.5}^{n}}{\left(\rho_{i}\right)_{k+0.5}^{n}}\right]- \\
& -0.5\left(\left(u_{i}^{2}\right)_{k+0.5}^{n+1}-\left(u_{i}^{2}\right)_{k+0.5}^{n}\right)
\end{aligned}
$$

The volume concentration is found from the formula

$$
\begin{array}{r}
\left(\alpha_{i}\right)_{k+0.5}^{n+1}=\left(\alpha_{i}\right)_{k+0.5}^{n}-\tau\left[( \alpha _ { i } ) _ { k + 0 . 5 } ^ { n } ( \rho _ { i } ) _ { k + 0 . 5 } ^ { n } \left(U_{k+0.5}^{n}-\left(u_{i}\right)_{k+0.5}^{n} \frac{\left(\alpha_{i}\right)_{k+1}^{*}-\left(\alpha_{i}\right)_{k}^{*}}{\left(h_{i}\right)_{k+0.5}^{n}}+\right.\right. \\
\left.+\left(\Omega_{i}\right)_{k+0.5}^{n}+\left(B_{i}\right)_{k+0.5}^{n}\right] .
\end{array}
$$

The rest quantities are independent of the problem symmetry. Here, the following notation is also introduced:

$$
\begin{gathered}
\left(\rho_{i}\right)_{k+0.5}^{n+1}=\frac{\left(\alpha_{i} \rho_{i}\right)_{k+0.5}^{n+1}}{\left(\alpha_{i}\right)_{k+0.5}^{n+1}}, \\
\left(P_{i}\right)_{k+0.5}^{n+1}=f_{i}\left(\left(\rho_{i}\right)_{k+0.5}^{n+1},\left(E_{i}\right)_{k+0.5}^{n+1}\right),
\end{gathered}
$$




$$
\begin{gathered}
\left(F_{i}\right)_{k+0.5}^{n+1}=-0.5\left(\rho_{i}\right)_{k+0.5}^{n+1}\left(U_{k+0.5}^{n+1}-\left(u_{i}\right)_{k+0.5}^{n+1}\right)^{2} \\
\left(Q_{i}\right)_{k+0.5}^{n+1}=\frac{1}{2}\left(U_{k+0.5}^{n+1}-\left(u_{i}\right)_{k+0.5}^{n+1}\right)\left(\left(P_{i}\right)_{k+0.5}^{n+1}+\left(\rho_{i}\right)_{k+0.5}^{n+1}\left(E_{i}\right)_{k+0.5}^{n+1}\right), \\
\left(R_{i}\right)_{k+0.5}^{n+1}=\left(\alpha_{i}\right)_{k+0.5}^{n+1} \sum_{j=1}^{N}\left(\alpha_{j}\right)_{k+0.5}^{n+1}\left(R_{i j}\right)_{k+0.5}^{n+1}=\left(\alpha_{i}\right)_{k+0.5}^{n+1} \sum_{j=1}^{N}\left(\alpha_{j}\right)_{k+0.5}^{n+1} a_{i j}\left(\left(u_{j}\right)_{k+0.5}^{n+1}-\left(u_{i}\right)_{k+0.5}^{n+1}\right), \\
\left(\Phi_{i}\right)_{k+0.5}^{n+1}=\left(\alpha_{i}\right)_{k+0.5}^{n+1} \sum_{j=1}^{N}\left(\alpha_{j}\right)_{k+0.5}^{n+1}\left(\Phi_{i j}\right)_{k+0.5}^{n+1}=\left(\alpha_{i}\right)_{k+0.5}^{n+1} \sum_{j=1}^{N}\left(\alpha_{j}\right)_{k+0.5}^{n+1} b_{i j}\left(\left(P_{j}\right)_{k+0.5}^{n+1}-\left(P_{i}\right)_{k+0.5}^{n+1}\right) \\
\left(\Omega_{i}\right)_{k+0.5}^{n+1}=\left(\alpha_{i}\right)_{k+0.5}^{n+1} \sum_{j=1}^{N}\left(\alpha_{j}\right)_{k+0.5}^{n+1} \frac{b_{i j}\left(\left(P_{j}\right)_{k+0.5}^{n+1}-\left(P_{i}\right)_{k+0.5}^{n+1}\right)}{\left(\left(c_{i}\right)_{k+0.5}^{n+1}+\left(c_{j}\right)_{k+0.5}^{n+1}\right)\left(\left(\rho_{i}\right)_{k+0.5}^{n+1}\left(c_{i}\right)_{k+0.5}^{n+1}+\left(\rho_{j}\right)_{k+0.5}^{n+1}\left(c_{j}\right)_{k+0.5}^{n+1}\right)} \\
\left(A_{i}\right)_{k+0.5}^{n+1}=\left(\alpha_{i}\right)_{k+0.5}^{n+1} \sum_{j=1}^{N}\left(\alpha_{j}\right)_{k+0.5}^{n+1} a_{i j} \frac{\left(\left(u_{j}\right)_{k+0.5}^{n+1}\right)^{2}-\left(\left(u_{i}\right)_{k+0.5}^{n+1}\right)^{2}}{2} \\
\left(B_{i}\right)_{k+0.5}^{n+1}=\left(\alpha_{i}\right)_{k+0.5}^{n+1} \sum_{j=1}^{N}\left(\alpha_{j}\right)_{k+0.5}^{n+1} d_{i j} a_{i j} \frac{\left(\left(u_{j}\right)_{k+0.5}^{n+1}\right)^{2}-\left(\left(u_{i}\right)_{k+0.5}^{n+1}\right)^{2}}{2}
\end{gathered}
$$

where $c_{i}=\sqrt{\frac{P_{i}}{\rho_{i}^{2}}\left(\frac{\partial P_{i}}{\partial E_{i}}\right)_{\rho_{i}}+\left(\frac{\partial P_{i}}{\partial \rho_{i}}\right)_{E_{i}}}$, or in the difference form

$$
\left(c_{i}\right)_{k-0.5}^{n}=\sqrt{\frac{\left(P_{i}\right)_{k-0.5}^{n}}{\left(\rho_{i}^{2}\right)_{k-0.5}^{n}}\left[\left(\frac{\partial P_{i}}{\partial E_{i}}\right)_{\rho_{i}}\right]_{k-0.5}^{n}+\left[\left(\frac{\partial P_{i}}{\partial \rho_{i}}\right)_{E_{i}}\right]_{k-0.5}^{n}}
$$

\subsection{The Eulerian Stage}

After the auxiliary and main quantities for each component are determined on the Lagrangian grid, it is necessary to convert quantities from the "old" grid (obtained after the Lagrangian stage) to the "new" grid (unified three-dimensional grid).

Let a cell in the new grid of size $\Delta x$ has $L$ old grid cells wherein the solution is already found, i.e. quantities $\Delta x_{k},\left(\rho_{i}\right)_{k},\left(u_{i}\right)_{k},\left(P_{i}\right)_{k}$ are known. Note that one part of the old grid cells wholly fall within the cell and the other part - only partially. It is important that values $\Delta x_{k}$ satisfy the condition:

$$
\Delta x=\sum_{k=1}^{L} \Delta x_{k}
$$

Masses of old grid cells and also the mass of the Eulerian cells are determined from the following equations

$$
\begin{gathered}
\left(\Delta M_{i}\right)_{k}=\left(\rho_{i}\right)_{k} \Delta x_{k}, \\
\Delta M=\sum_{k=1}^{L} \Delta M_{k} .
\end{gathered}
$$


Let us introduce the volumetric and mass concentrations

$$
\alpha_{k}=\frac{\Delta x_{k}}{\Delta x}, \quad \xi_{k}=\frac{\Delta M_{k}}{\Delta M} .
$$

It follows that $\left(\alpha_{i}\right)_{k},\left(\rho_{i}\right)_{k}$ satisfy the conditions

$$
\sum_{k=1}^{L} \alpha_{k}=1, \quad \sum_{k=1}^{L} \xi_{k}=1
$$

Obeying the mass, momentum, and energy conservation laws, we derive equations to determine quantities of the averages in the new cell

$$
\rho_{i}=\sum_{k=1}^{L} \alpha_{k}\left(\rho_{i}\right)_{k}, \quad u_{i}=\sum_{k=1}^{L} \xi_{k}\left(u_{i}\right)_{k}, \quad E_{i}=\sum_{k=1}^{L} \xi_{k}\left(E_{k}+0.5\left(\left(u_{i}\right)_{k}-U\right)^{2}\right) .
$$

\section{Statement of the Problem}

Let us consider the test problem on the steady shock-wave propagation in a homogeneous mixture of two polyatomic ideal gases (with the equation of state $P=(\gamma-1) \rho E)$. Suppose this mixture is in the enclosed volume and each gas is in the state of rest. Pressure of each component is assumed to be equal to zero, volume concentrations of gases are equal in value, $\gamma_{1}=\gamma_{2}=\frac{5}{3}$. Density of a light gas equals 1 and density of a heavy gas equals 2 . A boundary condition is established, i.e. a rigid wall moving at rate 1 (see Fig. 2).

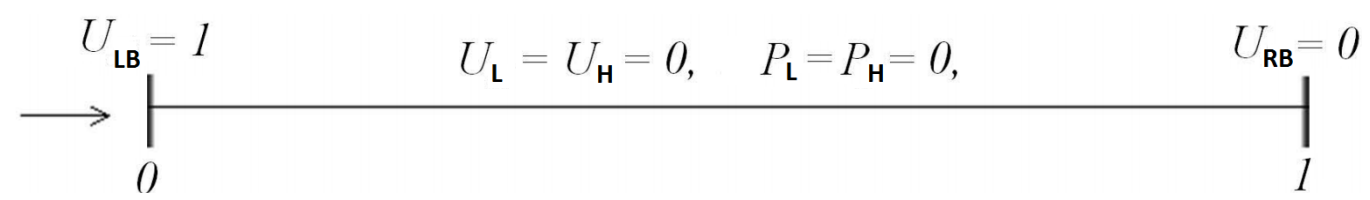

Fig. 2. Statement of the problem. Parameters of the light gas are denoted by letter L and parameters of the heavy gas - by letter $\mathrm{H}$.

\section{Results of Numerical Simulation}

The method presented in Section 1 was used to perform computations in the above problem. Our calculations used different values of parameters $a_{12}$ and $b_{12}$, responsible for pairwise interaction. Consider different situations in calculations with cluster interaction that is universal and independent of the components' state.

\subsection{Only Cluster Interaction $\left(a_{12}=0, b_{12}=0\right)$}

Figures 3-5 show profiles of density, pressure, and velocity at the time $t=0.5$.

These results obviously demonstrate that cluster interaction equalizes mass velocities of components. Thus, it makes no sense to increase velocity relaxation behind the shock front through increment of the parameter $a_{12}$ in the case of pairwise interaction against cluster interaction. Hence, we must increment the parameter $b_{12}$ in order to estimate contribution of pairwise interaction against cluster interaction. 


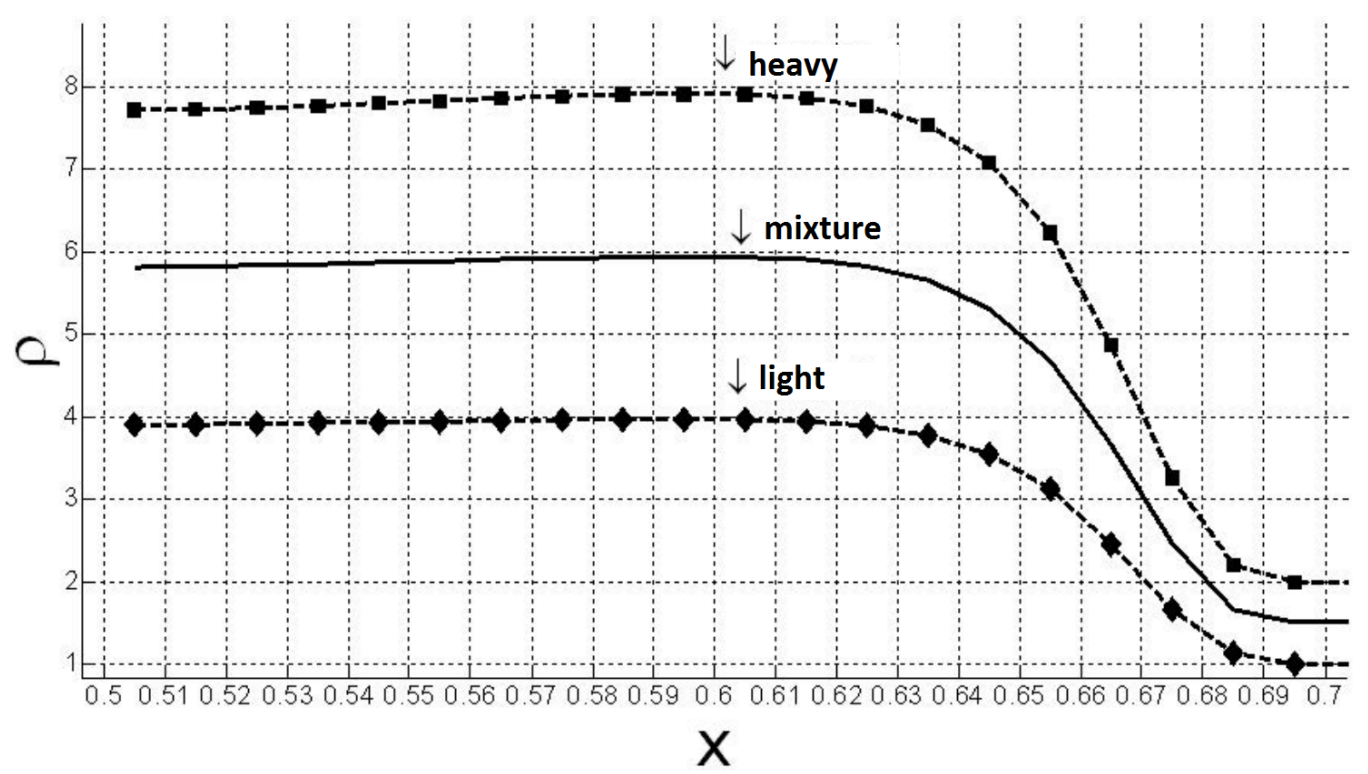

Fig. 3. Density profiles for the light gas, the heavy gas, and their mixture

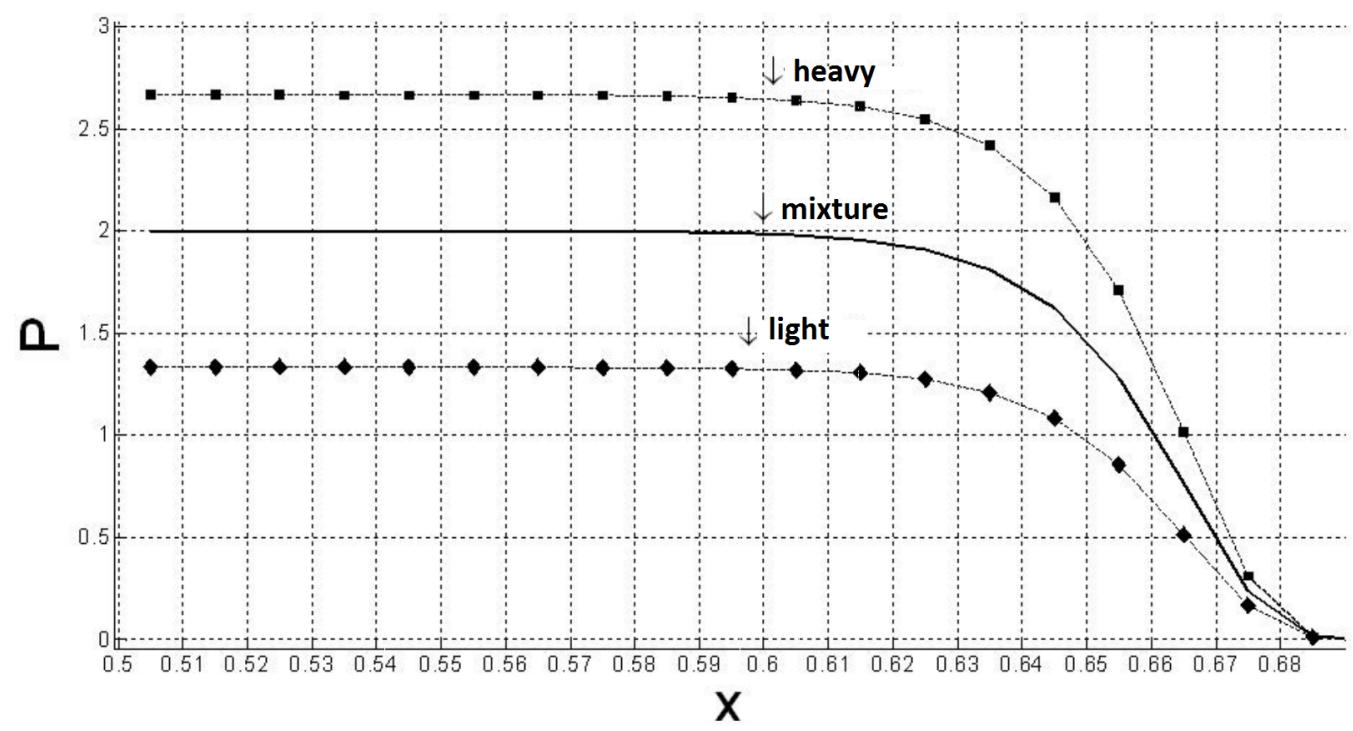

Fig. 4. Pressure profiles for the light gas, the heavy gas, and their mixture

\subsection{Pairwise Interaction in the Presence of Cluster Interaction, Pressure Exchange $\left(a_{12}=0, b_{12}=10\right)$}

Figures 6-8 show profiles of density, pressure, and velocity at the time $t=0.5$.

It is easily seen that notable increment of the parameter $b_{12}$ does not result in significant pressure relaxation behind the shock front. Also, mass velocities are noted to differ in the vicinity of the front, i.e. the light component is accelerating first and then it urges the heavy component to increase its velocity. 


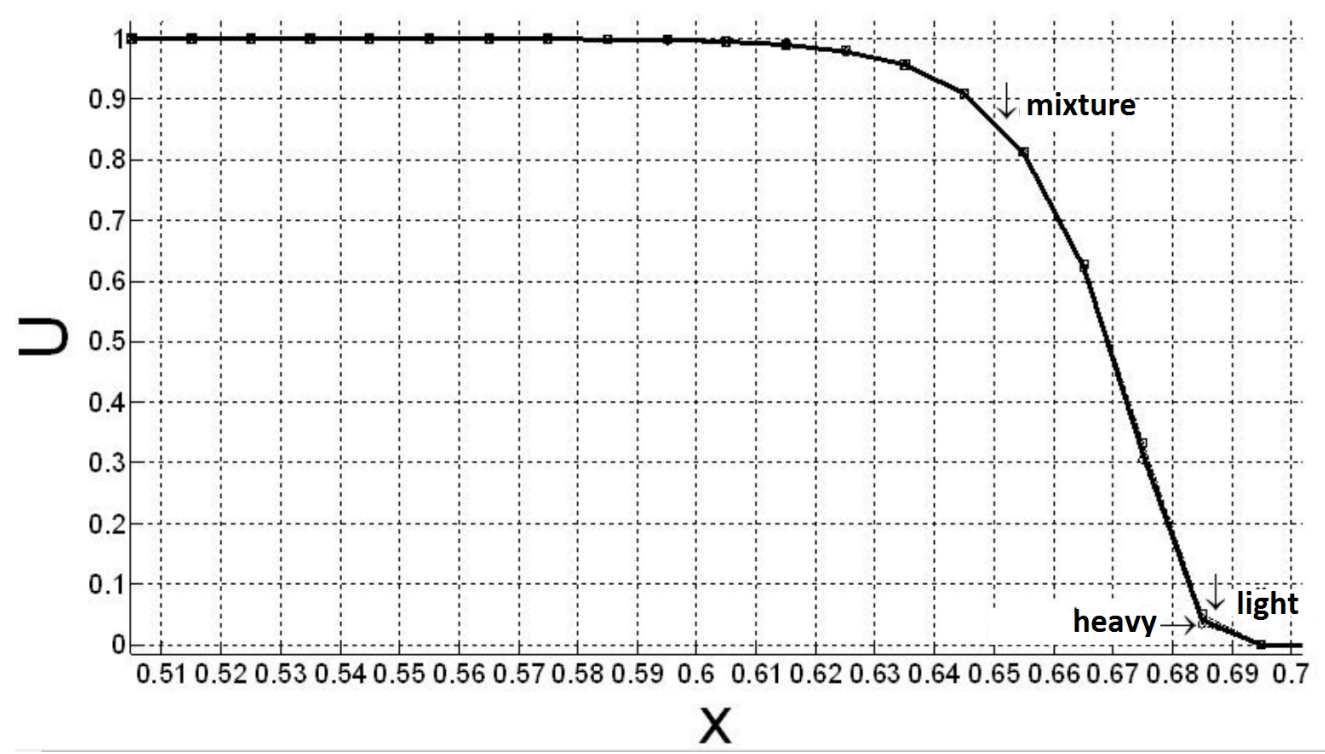

Fig. 5. Mass velocity profiles for the light gas, the heavy gas, and their mixture

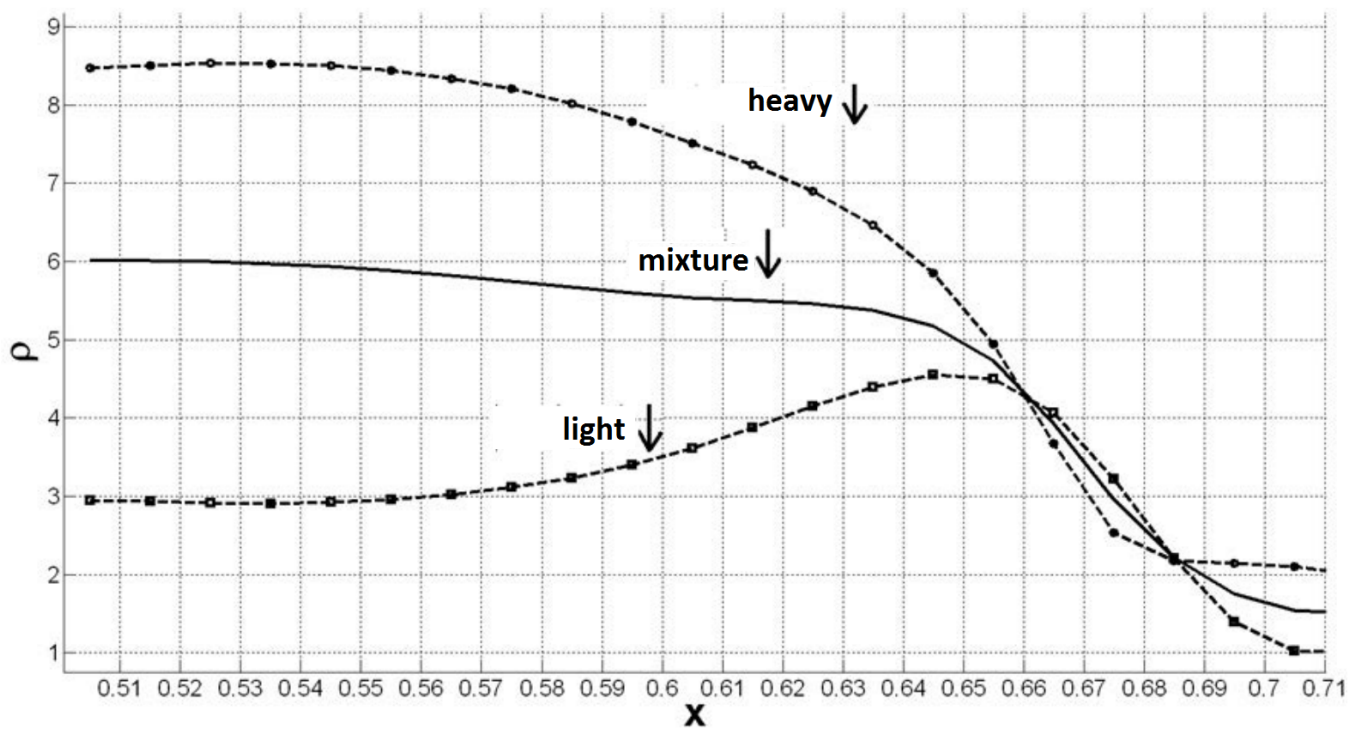

Fig. 6. Density profiles for the light gas, the heavy gas, and their mixture

\section{Conclusion}

The method for determining auxiliary quantities, which is based on the conservations laws on the strong discontinuity in mixtures, is developed. One-dimensional calculations of the shock-wave propagation in the plane layer of two gases are performed. The numerical solution proves to be adequate as for variation of physical quantities. Different values of component interaction parameters are considered. Flow parameters are shown to depend on cluster interaction. 


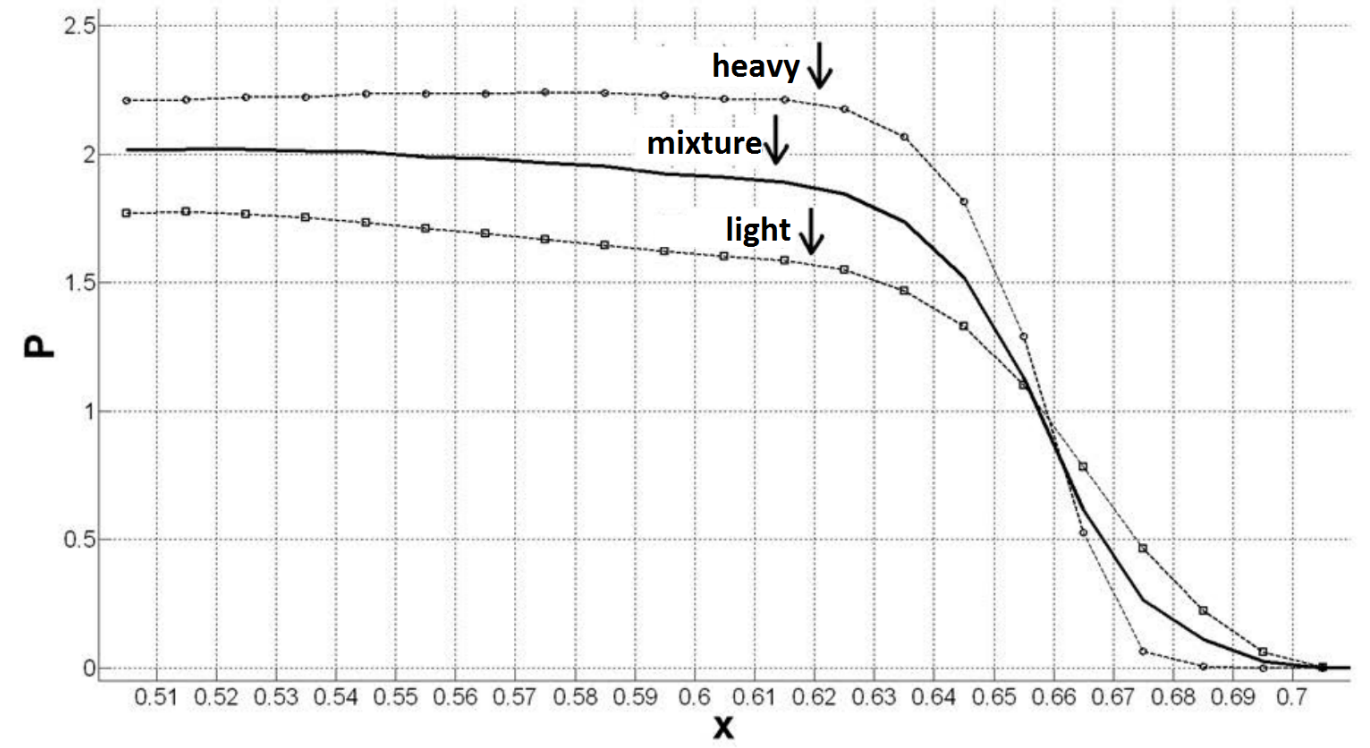

Fig. 7. Pressure profiles for the light gas, the heavy gas, and their mixture

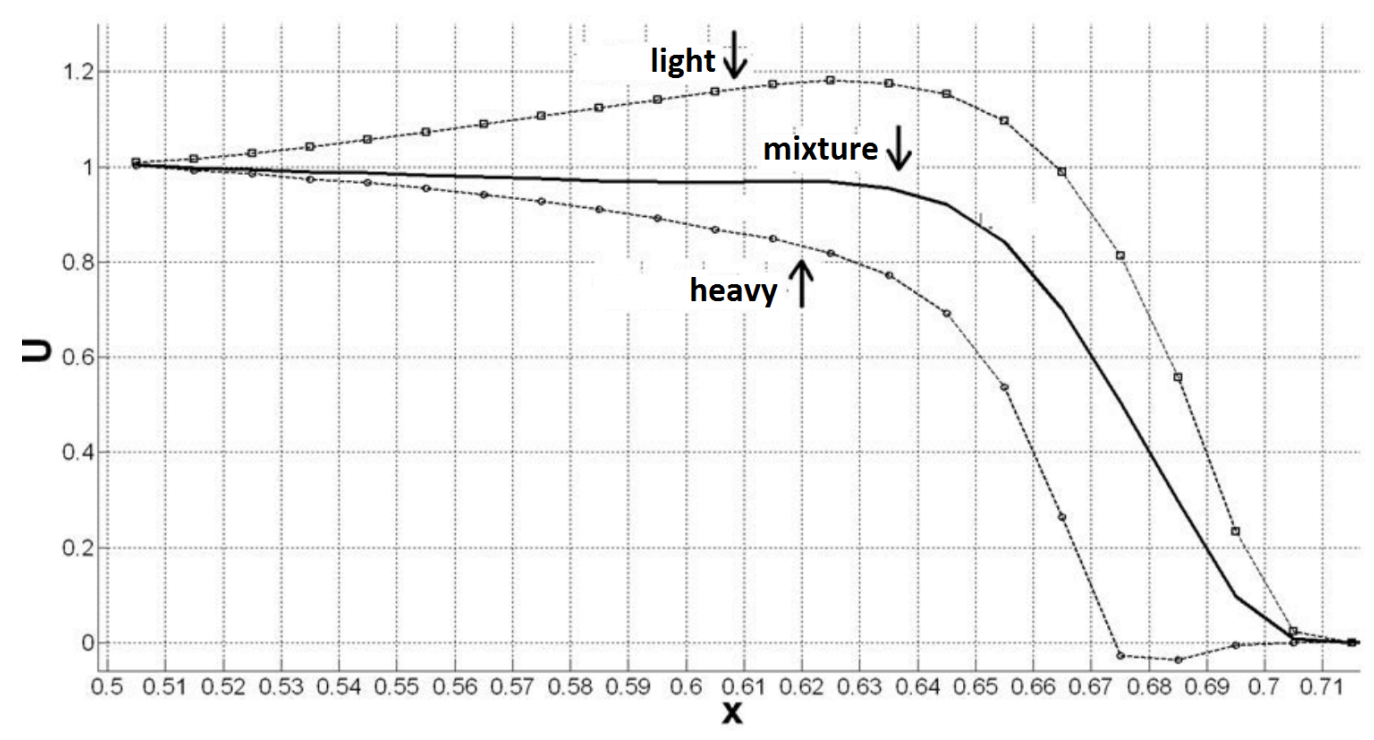

Fig. 8. Mass velocity profiles for the light gas, the heavy gas, and their mixture

\section{References}

1. Kuropatenko V. F. New Models of Continuum Mechanics. Journal of Engineering Physics and Thermophysics, 2011, vol. 84, no. 1, pp. 74-92. doi: 10.1007/s10891-0110457-0.

2. Kovalev Yu. M., Kuropatenko V. F. Analysis of the Invariance Some Mathematical Models of Multicomponent Media. Bulletin of the South Ural State University. Series: Mathematics. Mechanics. Physics, 2012, issue 6, no. 11 (270), pp. 4-7. (in Russian).

3. Kuropatenko V. F., Shestakovskaya E. S. [Fundamentals of Continuum Mechanics Numerical Methods]. Chelyabinsk, South Ural State University, 2017. (in Russian). 
4. Kuropatenko V. F. A Shock Capturing Method. Bulletin of the South Ural State University. Series: Mathematical Modelling, Programming and Computer Software, 2014, vol. 7, no. 1, pp. 62-75. (in Russian). doi: 10.14529/mmp140106.

5. Kuropatenko V. F. [Models of Continuum Mechanics]. Chelyabinsk, Chelyabinsk State University, 2007. (in Russian).

Aleksandr V. Krasilnikov, Junior Researcher, Russian Federal Nuclear Center Academician E. I. Zababakhin All-Russian Research Institute of Technical Physics (Snezhinsk, Russian Federation); PhD Student, Department of Computational Mechanics, South Ural State University (Chelyabinsk, Russian Federation), press-csu@yandex.ru.

Valentin F. Kuropatenko, DSc (Math), Chief Researcher, Russian Federal Nuclear Center-Academician E. I. Zababakhin All-Russian Research Institute of Technical Physics (Snezhinsk, Russian Federation).

Received August 14, 2018.

УДК $519.63+532.529$

DOI: $10.14529 /$ jcem 180305

\title{
О РАСПРОСТРАНЕНИИ СИЛЬНОГО РАЗРЫВА В ДВУХКОМПОНЕНТНОЙ СМЕСИ ГАЗОВ
}

\author{
А. В. Красильников, В.Ф. Куропатенко
}

\begin{abstract}
Сильные разрывы - ударные волны возникают в сплошной среде при динамических внешних воздействиях. При моделировании их распространения в смесях веществ для каждого из компонентов необходимо учитывать законы сохранения массы, импульса и энергии, связывающие состояния вещества перед поверхностью разрыва и за ней. В данной работе рассчитывается процесс распространения ударной волны в плоском слое - гомогенной смеси двух газов различной плотности. Для этого численно реализовывались законы сохранения и величины, отвечающие за взаимодействие компонентов. Расчеты выполнялись лагранжево-эйлеровым методом. На лагранжевом этапе был использован метод расчета ударных волн, основанный на решении системы нелинейных алгебраических уравнений. Исследовано влияние кластерного и парного взаимодействий на параметры течения. Показано, что наибольший вклад в релаксацию скоростей за фронтом сильного разрыва дает именно кластерное взаимодействие. При различных параметрах взаимодействия получены профили термодинамических величин и массовых скоростей для каждого из компонентов.

Ключевые слова: многокомпонентная среда; законы сохранения; ударная волна; лагранжево-эйлерова схема; кластерное взаимодействие.
\end{abstract}

\section{Литература}

1. Куропатенко, В. Ф. Новые модели механики сплошных сред / В. Ф. Куропатенко // Инженерно-физический журнал. - 2011. - Т. 4, № 1. - С. 74-92. 
2. Ковалев, Ю. М. Анализ инвариантности некоторых математических моделей многокомпонентных сред / Ю. М. Ковалев, В. Ф. Куропатенко // Вестник ЮУрГУ. Серия: Математика. Механика. Физика. - 2012. - Вып. 6, № 11 (270). - С. 4-7.

3. Куропатенко, В. Ф. Основы численных методов механики сплошной среды / В. Ф. Куропатенко, Е. С. Шестаковская. - Челябинск: Издательский центр ЮУрГУ, 2017.

4. Куропатенко, В. Ф. Об одном методе сквозного счета ударных волн / В. Ф. Куропатенко // Вестник ЮУрГУ. Серия: Математическое моделирование и программирование. - 2014. - Т. 7, № 1. - С. 62-75.

5. Куропатенко, В. Ф. Модели механики сплошных сред / В. Ф. Куропатенко. Челябинск: Челяб. гос. ун-т, 2007.

Красильников Александр Владимирович, младиий научный сотрудник, Российский федеральный ядерный центр - Всероссийский научно-исследовательский институт технической физики имени академика Е. И. Забабахина (г. Снежинск, Российская Федерачия); аспирант, кафедра вычислительной механики, ЮжноУральский государственный университет (г. Челябинск, Российская Федераиия), press-csu@yandex.ru.

Куропатенко Валентин Федорович, главный научный сотрудник, Российский федеральный ядерный иентр - Всероссийский научно-исследовательский институт технической физики имени академика Е. И. Забабахина (ә. Снежинск, Российская Федерачия).

Поступила в редакиию 14 августа 2018 г. 